Review

\title{
A review of Bayesian belief network models as decision-support tools for wetland conservation: Are water birds potential umbrella taxa?
}

\author{
Maggie P. MacPherson ${ }^{\mathrm{a}, *}$, Elisabeth B. Webb1 ${ }^{\mathrm{b}}, 2^{\mathrm{a}}$, Andrew Raedeke ${ }^{\mathrm{c}}$, Doreen Mengel ${ }^{\mathrm{c}}$, Frank Nelson ${ }^{\mathrm{c}}$ \\ a School of Natural Resources, University of Missouri, Columbia, MO, United States of America \\ ${ }^{\mathrm{b}}$ U.S. Geological Survey, Missouri Cooperative Fish and Wildlife Research Unit, United States of America \\ ${ }^{\mathrm{c}}$ Missouri Department of Conservation, Columbia, MO, United States of America
}

\section{A R T I C L E I N F O}

Keywords:

BBN

Species distribution model

Translational science

Netica

Expert knowledge

\begin{abstract}
A B S T R A C T
Creative approaches to identifying umbrella species hold promise for devising effective surrogates of ecological communities or ecosystems. However, mechanistic niche models that predict range or habitat overlap among species may yet lack development. We reviewed literature on taxon-centered Bayesian belief network (BBN) models to explore a novel approach to identify umbrella taxa identifying taxonomic groups that share the largest proportion of habitat requirements (i.e., states of important habitat variables) with other wetland-dependent taxa. We reviewed and compiled published literature to provide a comprehensive and reproducible account of the current understanding of habitat requirements for freshwater, wetland-dependent taxa using BBNs. We found that wetland birds had the highest degree of shared habitat requirements with other taxa, and consequently may be suitable umbrella taxa in freshwater wetlands. Comparing habitat requirements using a BBN approach to build species distribution models, this review also identified taxa that may not benefit from conservation actions targeted at umbrella taxa by identifying taxa with unique habitat requirements not shared with umbrellas. Using a standard node set that accurately and comprehensively represents the ecosystem in question, BBNs could be designed to improve identification of umbrella taxa. In wetlands, expert knowledge about hydrology, geomorphology and soils could add important information regarding physical landscape characteristics relevant to species. Thus, a systems-oriented framework may improve overarching inferences from BBNs and subsequent utility to conservation planning and management.
\end{abstract}

\section{Introduction}

Biological conservation relies on identifying and connecting species with the habitat requirements important for the successful completion of life cycles. Species distribution models (SDMs) are increasingly relied upon to identify habitat elements important for conservation (Dibner et al., 2017; Phillips et al., 2017). Predictive SDMs are particularly needed for understanding how species will respond to ongoing environmental change (Wood et al., 2018). Increased access to, and advances in technology have improved our ability to understand associations between species and their habitats (Elith and Leathwick, 2009). Technological advances include Geographic Information Systems (GIS) and remote sensing technology, paired with increased computing power and the development of spatial statistical models (e.g., Guisan and Thuiller, 2005). Examples of this approach include Gap Analysis Program (GAP) models mapping land cover and predicted distributions of species, bioclimatic envelopes, habitat suitability indices, maximum entropy models (MAXENT), and genetic algorithm for rule-set prediction (GARP; Elith et al., 2006; Guisan and Zimmermann, 2000; Sowa et al., 2007). The results of SDMs are commonly used to build species-specific Habitat Suitability Indices (HSIs) that estimate the probability of species presence across a landscape and have been used extensively in conservation planning (Zajac et al., 2015). Thus, identifying the key elements of habitat for species of conservation concern is important for informing conservation actions (Lin et al., 2018).

Bayesian belief networks (BBNs) represent one form of SDM that offer a unique modeling approach by identifying explicit causal relationships among organisms and their habitats, as well as incorporating measures of uncertainty. In the ecological literature, BBNs go beyond species-habitat correlations because they explicitly consider discrete processes that influence occupancy across space and time (i.e., access and selection; Jones, 2001). BBNs consist of input, intermediate and output nodes that are linked together via conditional probability tables

\footnotetext{
* Corresponding author at: Anheuser-Busch Natural Resources Building, University of Missouri, Columbia, MO 65211, United States of America.

Email address: macphersonm@missouri.edu (M.P. MacPherson)
} 
(CPTs) according to hypothesized causal relationships (Fig. 1; Drew and Collazo, 2014). As graphically based probabilistic models (i.e., influence diagrams), BBNs may incorporate information gleaned from literature reviews, expert opinions and monitoring efforts to examine how all possible values of environmental variables may influence the occurrence or distribution of individuals. Bayesian belief networks approach SDMs by exhaustively exploring potential ecological variables defining a species' niche while simultaneously incorporating metrics of uncertainty surrounding estimates of habitat requirements (Marcot et al., 2006; Uusitalo et al., 2015). The inclusion of measures of uncertainty is important as many conservation decisions must be made in the absence of complete information. Thus, a BBN modeling approach can be used to inform decisions made using an adaptive management approach to reduce uncertainty (Drew and Collazo, 2014).

The umbrella species concept (Wilcox, 1984) can enhance conservation for suites of species with similar habitat requirements by countering incomplete biodiversity surveys that lack time, financial support, or adequate methods. The umbrella species concept provides a framework to improve the effectiveness of conservation action while reducing the complexity of quantifying species-specific outcomes. Umbrella species are unique in that they represent an ecologically-defined role in conservation as managing for their life history needs is expected to serve other species that co-occur or rely on the same set of resources (Roberge and Agelstam, 2004). As such, umbrella species are habitat specialists with large ranges sizes, and that are often sensitive to environmental disturbance (Kalinkat et al., 2017). Creative approaches to identifying umbrella species hold promise for devising effective surrogates of ecological communities or ecosystems (Sattler et al., 2014), but mechanistic niche modeling for predicting overlap of species' ranges and habitat requirements can be developed by narrowing gaps in our understanding of species ecology (Kearney and Porter, 2009).

Efforts to quantitatively identify umbrella species from among multiple candidate taxa (Caro and O'Doherty, 1999; Fleishman et al., 2000; Maslo et al., 2016; Stewart et al., 2017) often focus solely on contrasting spatial overlap identified using potentially incomplete sets of environmental predictors (Andelman and Fagan, 2000; Seddon and Leech, 2008). Despite past mixed success of using umbrella species for conservation planning (e.g., successful: Fleishman et al., 2000; Roth and
Weber, 2007; Suter et al., 2002, unsuccessful: Launer and Murphy, 1994; Ozaki et al., 2006), the concept continues to improve by broadening to encompass both taxonomic and functional diversity (Sattler et al., 2014). Typical approaches to identifying umbrella species have used SDMs that lacked explicit mechanistic reasoning to identify spatial ranges (i.e., beyond spatial overlap to encompass responses to similar environmental conditions) (Cayuela et al., 2009; Elith and Leathwick, 2009). As the umbrella approach to wider species conservation holds promise for identifying effective surrogate taxa (Sattler et al., 2014), we present a method to identify umbrella taxa informed by suites of BBN models that represent spatial ranges with causal reasoning.

Given the ability of BBNs to generate spatially-explicit predictions based on functionally-defined species-habitat relationships, they represent a potentially valuable approach to evaluate a species' expected performance as an umbrella species. Therefore, we took a case study and literature review approach to identify potential umbrella taxa within an ecosystem using BBN models. Restricting our research to freshwater wetland ecosystems, we undertook a systematic literature review to quantify the categorical overlap of habitat requirements for freshwater wetland-dependent species among existing BBNs. We reviewed existing taxon-centered BBN models to: 1) assess how BBNs were constructed, 2) describe how BBNs were used to inform biological conservation and identify the extent BBNs appeared to be used by those making biological conservation decisions, and 3) identify candidate umbrella taxa.

We chose freshwater wetlands because of the important role they play for a large number of species and the widespread concern for their conservation (Dudgeon et al., 2006). Despite the numerous ecosystem services provided by wetlands, greater than $50 \%$ of wetland area in the contiguous United States (US) has been converted to agricultural and urban land use (Horvath et al., 2017). There is a growing recognition of the difficulties of wetland restoration to renew lost biodiversity and ecosystem function (Meli et al., 2014; Zedler, 2000). Multiple factors including habitat fragmentation, hydrological changes, the introduction of exotic species, and overpopulation of other native species combined with wetland loss are correlated with declines in wetland flora and fauna (Adams, 1999; Bunn and Arthington, 2002; Findlay and Houlahan, 1997; Kerbes et al., 1990; Knutson et al., 1999; Quesnelle et
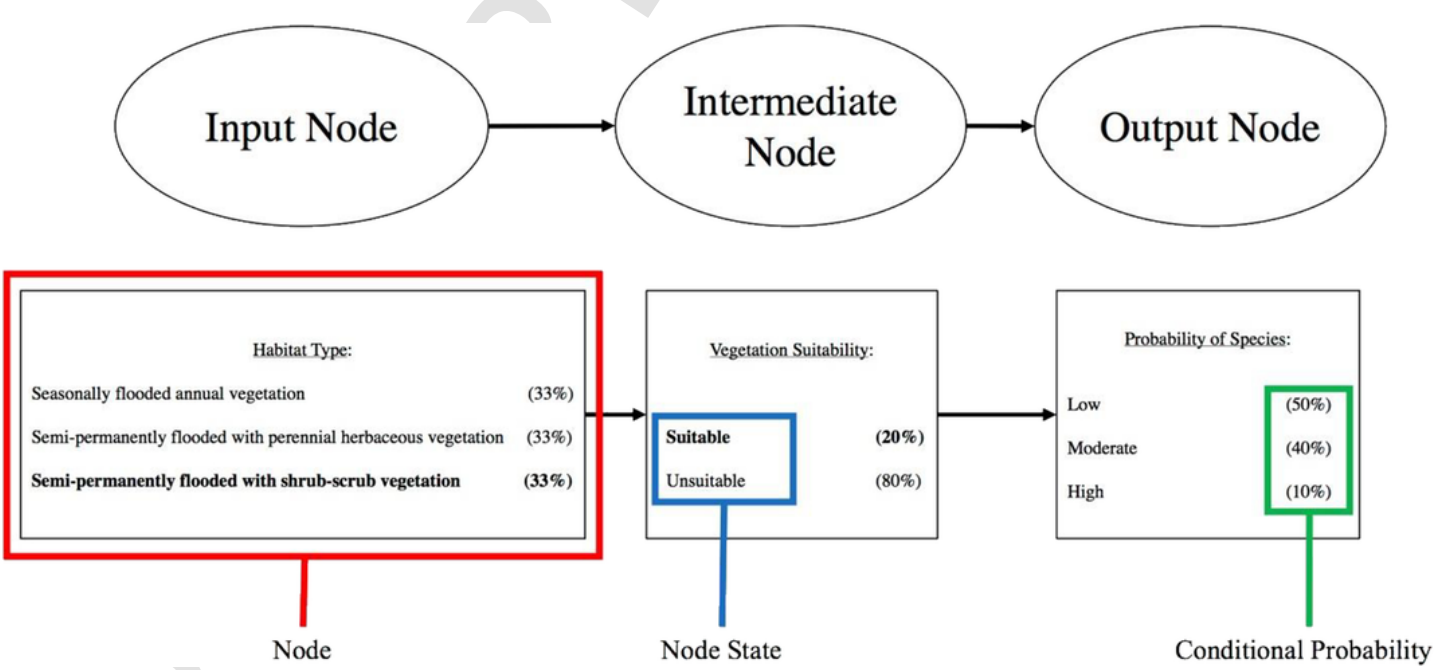

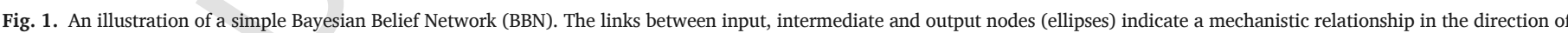

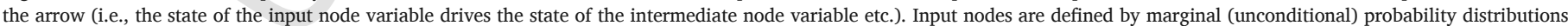

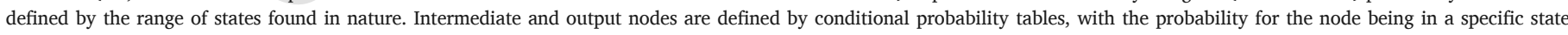

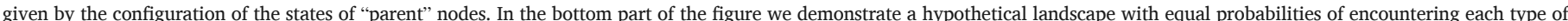

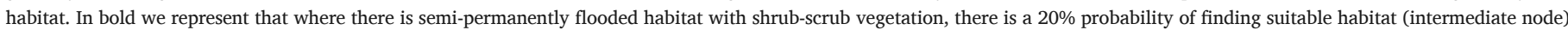

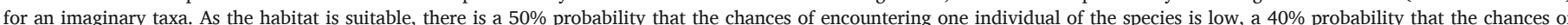

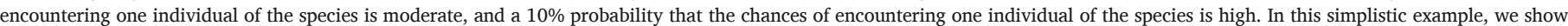
that the range of the probability of encountering the species (output node) changes based on the state at the input node. 
al., 2013; Wettstein and Schmid, 1999). Substantial wetland loss (Ramsar Convention Secretariat, 2013) and a paucity of restoration studies conducted in freshwater wetlands (Brudvig, 2011) further drive an urgency to identify conservation and restoration strategies that provide habitat for the breadth of wetland-dependent species (Galat et al., 1998; Lehtinen and Galatowitsch, 2001). Thus, approaching wetland conservation using a bottom-up framework to identify umbrella taxa in freshwater wetland ecosystems may creatively provide restoration targets (i.e., shared habitat requirements) to maximize the restoration of biodiversity in wetlands.

\section{Methods}

We systematically searched for and reviewed published literature to provide a comprehensive and reproducible overview of habitat requirements for freshwater wetland-dependent taxa using BBNs. We evaluated the scope of available peer-reviewed literature concerning habitat needs of freshwater wetland-dependent taxa, including identifying the presence of overlapping habitat requirements among taxa as well as collective sources of uncertainty. To do so, we searched the Google Scholar literature database using an 'abstract' search and with the publication date criteria set to 'anytime' (search undertaken in January 2018). We initially examined all English-language literature pertaining to freshwater wetland-dependent taxa, using the phrase "(wetland species AND Bayesian Belief Network AND species distribution model AND conditional probability table AND node)" (460 articles), to identify articles with published network models which we could compare. We then refined the search by including only publications that explored the distributions of species, rather than ecosystem or landscape-feature approaches. Our synthesis of the resulting publications consisted of four steps.

First, we summarized how BBNs were constructed. We compiled information on model type which included alpha-level (i.e., based on a literature review), beta-level (i.e., incorporated expert opinion), and gamma-level BBNs (i.e., included fieldwork to validate model predictions). We also compared model features including the number of nodes (i.e., BBN complexity), the sources and amount of uncertainty. Finally, we classified each BBN as either a process model (species-habitat relationships estimated for a single season or generalized across a life cycle) or dynamic model (relationships could vary from one time-period to another).

Then, we describe how BBNs were used to inform biological conservation and identified the extent to which BBNs appeared to be used by those making biological conservation decisions. There has been a recent call for translational science; translating what is learned from empirical research on species-habitat relationships into conservation action by developing tools accessible to decision makers such as resource managers (Littell et al., 2017). Given the emphasis on translational science and the promotion of BBNs as easy to understand models, one might expect use of BBN models in natural resource management to be common. To determine if this was the case, we compiled data for each publication on: publication type (journal vs report), journal category (applied or method development), and funding source. If BBNs are easily comprehensible due to their graphical nature, (Douglas and Newton, 2014), we expected to find evidence of their use as decision-support tools. By collecting these general criteria, we sought to identify potential gaps in the translation (i.e., from development to deployment) of the BBN approach in conservation.

Lastly, we examined the potential to identify umbrella species using BBNs. To do so, we identified important states of nodes (i.e., habitat requirements) shared across models to help identify potential umbrella taxa. Then, we summarized the BBN models that captured species-specific, mechanistically derived habitat requirements (sensu O'Hagan, 2012) to identify taxonomic groups that shared the largest proportion of habitat requirements. The taxonomic group that had the largest amount of overlap with the other taxonomic groups was considered a candidate umbrella taxa.

\section{Theory}

The taxon-centered BBN models used to inform our umbrella taxa investigation mechanistically identify specific habitat requirements across taxa in a given ecosystem. This approach supports future research to quantitatively distinguish priority habitat for the focus of conservation planning, as well as identifies taxa with unique habitat requirements or unique habitat types that may not benefit from conservation actions targeted at umbrella taxa.

\section{Results}

\subsection{BBN model construction}

We identified a total of 53 articles with ecological BBNs for freshwater wetland-dependent taxa; consisting of 33 peer-reviewed articles, 9 reports or conference proceedings, 10 master of science theses or doctoral dissertations, and 1 book chapter (Appendix 1). The majority of studies followed the same three-step trajectory. The first step created an alpha-level BBN through a literature review, although few studies provided details on their literature review ( $n=5$ studies provided literature review details). Next, all but one study elicited expert knowledge in a two-step process to refine and modify the alpha structures and build beta-level models. For the third step, over half of studies $(n=26)$ validated their beta-level models with field data, completing the study with a published gamma-level model. The primary output nodes (i.e., response variable) for these studies were either abundance of the taxa in question or habitat suitability for the taxa in question. Nearly all studies used process models; only a single study used a dynamic model. The one temporally dynamic model (Chee et al., 2016) was also the only study to use any type of spatial statistical framework (geospatially explicit resampling between time periods). A habitat suitability response was typically represented as a binary categorical variable of suitable versus not suitable.

Few articles $(n=7)$ discussed sources or levels of uncertainty. Articles that did estimate uncertainty surrounding the nodes that contributed the highest uncertainty in species outcomes identified the following sources: amount of flooded area, connectivity of different wetland patches, flood duration, maximum water temperature, interspecific competition, predation, and blood mercury measurements. Despite low reporting on any estimates of uncertainty (due to either data uncertainty or structural uncertainty), authors emphasized refining variable definitions if they could be interpreted in different ways by experts (i.e., structural uncertainty). Some examples of poorly defined variables included 'water quality' variables, determining the state of an individual plant or animal when two states are very similar, and the precise definition of outcomes following restoration.

\subsection{BBNs as tools for biological conservation of freshwater wetlands}

The sources of peer-review articles were primarily ecological journals (e.g., Ecological Indicators), the modeling journal, Environmental Modeling \& Software $(n=6)$, and conservation journals such as Biological Conservation $(n=2)$ and Conservation Biology $(n=1)$. Lead authorship on peer-reviewed articles and reports was rarely by graduate students or early-career scientists such as postdoctoral researchers (26\%), and more commonly by research fellows or senior researchers at the time of publication (Appendix 2).

The earliest evidence we found of BBNs being used to model habitat requirements of freshwater wetland species was from 2003, with an ac- 
celerated rate of increase in peer-reviewed literature using BBNs to explore habitat relationships of wetland taxa as years have gone on (Fig. 2). The majority of articles focused on Australasian wetlands (including Australia, Tasmania, Papua New Guinea, and New Zealand; 42\%), but wetlands from all continental regions (excepting Antarctica) have been represented by BBNs in the peer-reviewed literature (Appendix 1).

The most common taxonomic subjects were fish (Actineropterygii; $\mathrm{n}=15$ models), followed by macroinvertebrates (e.g., Amphipoda, Coleoptera, Gryllidae, Lepidoptera, etc.; $\mathrm{n}=10$ models) and birds (e.g., Ardeidae, Aythya affinis, Bucephala islandica, Dolichonyx oryzivorus, Grus canadensis, Hydrophasianus chirurgus, Megaceryle alcyon, Rallus elegans, Tympanuchus cupido, Tympanuchus phasianellus, Thryothorus ludovicianus; $\mathrm{n}=10$ models). In order of abundance, articles also included wetland plants (e.g., Galaxiella pusilla, Pilularia globulifera, Salicaceae, etc.; $\mathrm{n}=9$ models), bacteria (e.g., Escherichia coli; $\mathrm{n}=5$ models), fungi (e.g., $B a-$ trachochytrium dendrobatidis, Bridgeoporus nobilissimus, and Poronia punctata; $\mathrm{n}=3$ models), mammals (e.g., Corynorhinus townsendii, Lutrinae, Sus scrofa etc.; $\mathrm{n}=3$ models), amphibians (i.e., Anura; $\mathrm{n}=2$ models), reptiles (i.e., Testudines etc.; $\mathrm{n}=2$ models), and viruses (e.g., West Nile, malaria, etc.; $\mathrm{n}=2$ models). Four additional studies modeled habitat requirements for invasive species found in wetlands. Articles took the form of either single- or multi-species BBNs of predominantly data-poor species, with multi-species models developed if the environmental drivers of occupancy were shared across taxa.

Articles failed to identify a specific wetland type in 43\% (21/49 studies) of the literature we reviewed, instead simply referring to 'wetlands'. Ten out of 49 studies identified the modeled system as floodplain wetlands. In all these cases, the primary source of floodwaters was natural river connections rather than intentionally inundated through pumped water or other irrigation systems. Emergent wetlands were identified in 4/49 studies, and riparian wetlands were referred to in $3 / 49$ studies. Other descriptive terminology used to classify wetlands included slackwater, claypan, forested (including seeps), wet meadows, polders, artificial and temporary ( $2 \%$ or one article, each). We found no patterns between taxonomic group and the distinction of wetland types. That is, none of the taxonomic groups had BBNs built in single wetland types that could potentially have led to the identification of an overabundance of unique habitat requirements.

Based on information in the acknowledgements sections, the majority of peer-reviewed articles were funded through government agencies with a primary mission to support applied research to improve natural resource management, such the National Climate Change Adaptation Research Facility (Australia), the United States Fish and Wildlife Service (USA), and the United States Geological Survey (USA) (Appendix 2). There were fewer instances of funding from government agencies with a primary mission to advance science theory, such as the National Science Foundation (USA), the National Science Council (China) or the Natural Sciences and Engineering Research Council (Canada). Very few articles cited funding from nongovernmental organizations concerned with ecological restoration or biological conservation.

\subsection{Using BBNs to identify candidate umbrella taxa}

We found 38 habitat requirements reported for wetland-dependent taxa in our literature review (Table 1). The most frequent habitat requirement was presence of or persistence of water. Persistent water during the study period was identified as an important variable driving occurrence/abundance patterns in $24 \%$ of models ( $n=12$ models), spanning various taxonomic groups including amphibians, birds, fish, macroinvertebrates, mammals, and plants. The next most common habitat requirement was the appropriate timing (or "regularity") of seasonal flooding, by river inundation, rainfall or by irrigation ( $\mathrm{n}=10$ models). Appropriate timing of seasonal flooding was required by amphibians, bacteria, fish, macroinvertebrates, plants, and viruses, although was not included in models of birds, fungi, mammals or reptiles. Other common habitat requirements (each found in $n=8$ models) included deferment of effluent irrigation or pollution, total flooded area available, predictability of flood timing, extent, duration and frequency, and presence of a wooded border around wetlands. Less frequent habitat variables are listed in Table 1, along with those mentioned above.

The responses of bird species to environmental variables were the most complex, being sensitive to the broadest set of habitat variables ( $n=20 / 38$ habitat requirements were identified for bird species; Fig.
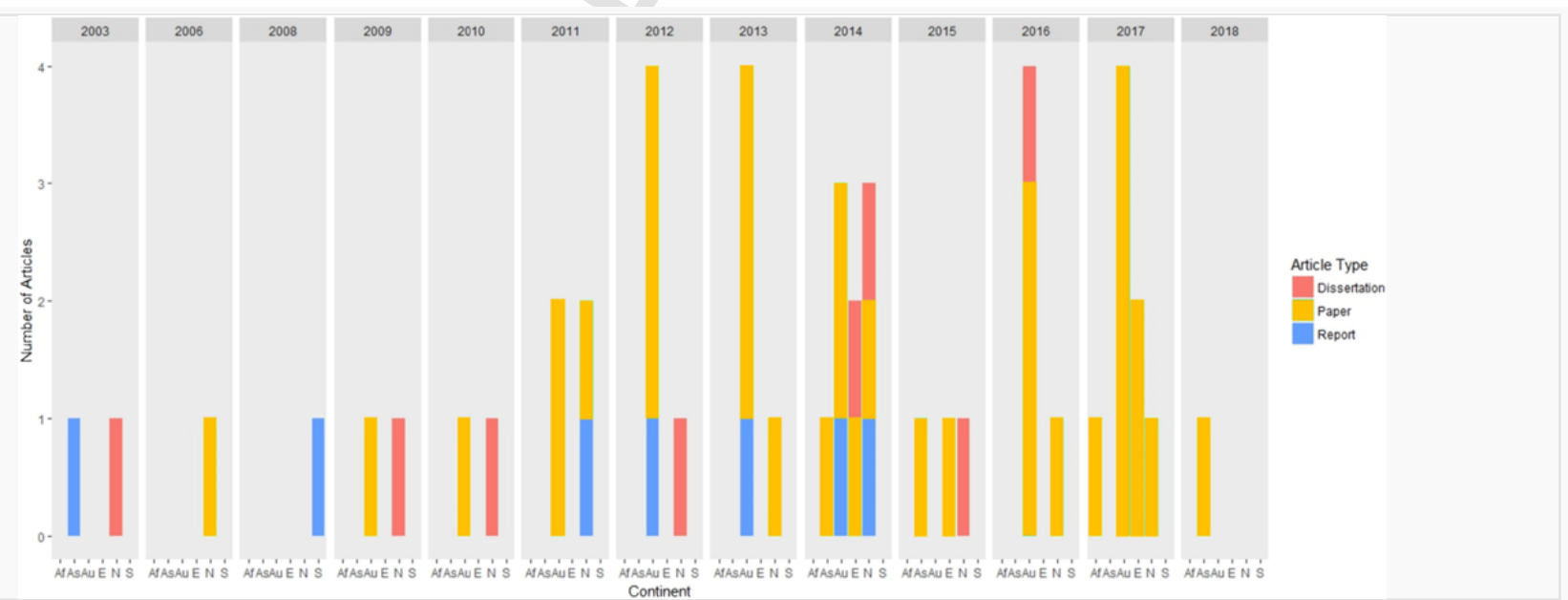

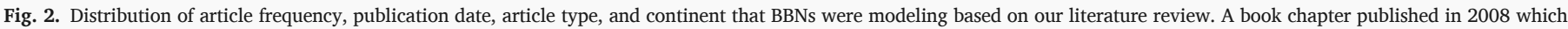

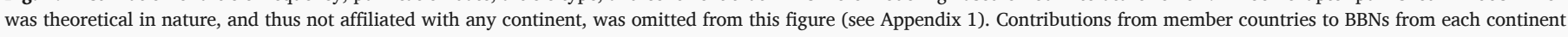

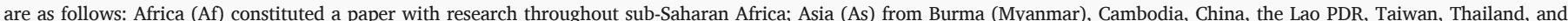

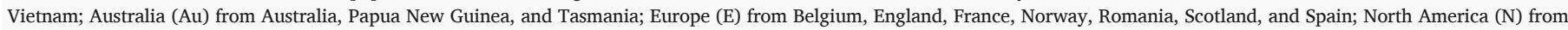

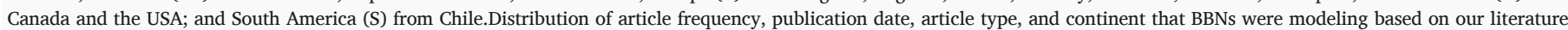

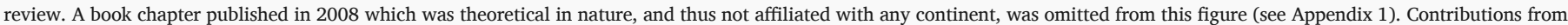

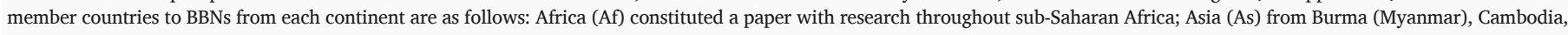

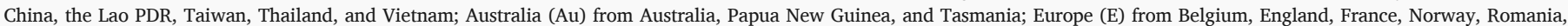
Scotland, and Spain; North America (N) from Canada and the USA; and South America (S) from Chile. 
Table 1

Habitat features that were the most important in determining occupancy or abundance of wetland-dependent taxa in our literature review. Features were determined as being important through sensitivity/percent entropy reduction analyses within the literature.

\begin{tabular}{|c|c|c|c|}
\hline & $\begin{array}{l}\text { Significant habitat } \\
\text { feature }\end{array}$ & $\begin{array}{l}\text { Number } \\
\text { of } \\
\text { studies }\end{array}$ & Dependent taxa \\
\hline 1 & Persistent water & 12 & $\begin{array}{l}\text { Amphibians, birds, fish, } \\
\text { macroinvertebrates, } \\
\text { mammals, plants }\end{array}$ \\
\hline 2 & $\begin{array}{l}\text { Regular flooding or } \\
\text { irrigation }\end{array}$ & 10 & $\begin{array}{l}\text { Amphibians, bacteria, } \\
\text { fish, } \\
\text { macroinvertebrates, } \\
\text { plants, viruses }\end{array}$ \\
\hline 3 & $\begin{array}{l}\text { Deferring effluent } \\
\text { irrigation or pollution }\end{array}$ & 8 & $\begin{array}{l}\text { Amphibians, bacteria, } \\
\text { birds, fish, } \\
\text { macroinvertebrates, } \\
\text { plants }\end{array}$ \\
\hline 4 & Total area flooded & 8 & $\begin{array}{l}\text { Birds, fish, mammals, } \\
\text { plants }\end{array}$ \\
\hline 5 & $\begin{array}{l}\text { Predictable timing, } \\
\text { extent, duration and } \\
\text { frequency of flooding }\end{array}$ & 8 & $\begin{array}{l}\text { Amphibians, bacteria, } \\
\text { birds, fish, fungi, } \\
\text { macroinvertebrates, } \\
\text { plants, viruses }\end{array}$ \\
\hline 6 & $\begin{array}{l}\text { Woody border to } \\
\text { wetland (woody shrub, } \\
\text { forest or riparian } \\
\text { border) }\end{array}$ & 8 & $\begin{array}{l}\text { Amphibians, bacteria, } \\
\text { birds, fish, fungi, } \\
\text { macroinvertebrates, } \\
\text { plants, reptiles }\end{array}$ \\
\hline 7 & Burn history & 5 & $\begin{array}{l}\text { Amphibians, birds, fish, } \\
\text { fungi, } \\
\text { macroinvertebrates, } \\
\text { plants }\end{array}$ \\
\hline 8 & Thermal tolerance & 5 & $\begin{array}{l}\text { Amphibians, birds, fish, } \\
\text { macroinvertebrates, } \\
\text { plants }\end{array}$ \\
\hline 9 & Grazing or trampling & 4 & $\begin{array}{l}\text { Birds, fungi, } \\
\text { macroinvertebrates, } \\
\text { plants }\end{array}$ \\
\hline 10 & $\begin{array}{l}\text { Specific location of } \\
\text { habitat }\end{array}$ & 4 & $\begin{array}{l}\text { Birds, fish, mammals, } \\
\text { reptiles }\end{array}$ \\
\hline 11 & Disturbance & 3 & $\begin{array}{l}\text { Bacteria, birds, fish, } \\
\text { reptiles }\end{array}$ \\
\hline 12 & $\begin{array}{l}\text { Erosion control/ } \\
\text { aggradation }\end{array}$ & 3 & $\begin{array}{l}\text { Fish, } \\
\text { macroinvertebrates }\end{array}$ \\
\hline 13 & Food availability & 3 & $\begin{array}{l}\text { Birds, mammals, } \\
\text { reptiles }\end{array}$ \\
\hline 14 & $\begin{array}{l}\text { Availability of specific } \\
\text { habitat type }\end{array}$ & 3 & $\begin{array}{l}\text { Amphibians, birds, fish, } \\
\text { mammals, plants }\end{array}$ \\
\hline 15 & $\begin{array}{l}\text { Connectivity between } \\
\text { habitats }\end{array}$ & 2 & $\begin{array}{l}\text { Amphibians, birds, } \\
\text { macroinvertebrates, } \\
\text { plants }\end{array}$ \\
\hline 16 & Interspecific competition & 2 & Bacteria \\
\hline 17 & $\begin{array}{l}\text { Amount of surrounding } \\
\text { agriculture }\end{array}$ & 2 & Birds, plants \\
\hline 18 & $\begin{array}{l}\text { Distance to roads or } \\
\text { density of roads }\end{array}$ & 2 & Birds, mammals \\
\hline 19 & $\begin{array}{l}\text { Mosquito breeding } \\
\text { ability }\end{array}$ & 2 & Viruses \\
\hline 20 & $\begin{array}{l}\text { Symbiotic relationships } \\
\text { with another species }\end{array}$ & 2 & Birds, plants \\
\hline 21 & $\begin{array}{l}\text { Precise timing of } \\
\text { management regime }\end{array}$ & 2 & Birds, fish \\
\hline 22 & Air temperature & 1 & Viruses \\
\hline 23 & $\begin{array}{l}\text { Control of non-native } \\
\text { plants }\end{array}$ & 1 & $\begin{array}{l}\text { Macroinvertebrates, } \\
\text { reptiles }\end{array}$ \\
\hline 24 & $\begin{array}{l}\text { Dissolved oxygen } \\
\text { content of water }\end{array}$ & 1 & Macroinvertebrates \\
\hline 25 & Groundwater depth & 1 & Plants \\
\hline 26 & $\begin{array}{l}\text { Surrounding human } \\
\text { population density }\end{array}$ & 1 & Viruses \\
\hline 27 & Urban development & 1 & Birds \\
\hline 28 & $\begin{array}{l}\text { Natural plain banking } \\
\text { wetland }\end{array}$ & 1 & Fish \\
\hline 29 & Parasites/pathogens & 1 & Reptiles \\
\hline
\end{tabular}

Table 1 (Continued)

\begin{tabular}{|c|c|c|c|}
\hline & $\begin{array}{l}\text { Significant habitat } \\
\text { feature }\end{array}$ & $\begin{array}{l}\text { Number } \\
\text { of } \\
\text { studies }\end{array}$ & Dependent taxa \\
\hline 30 & $\begin{array}{l}\text { Meters of wetland } \\
\text { perimeter habitat }\end{array}$ & 1 & Birds \\
\hline 31 & Predation & 1 & Bacteria, reptiles \\
\hline 32 & Rate of wetland drying & 1 & Plants \\
\hline 33 & Salt-water intrusion & 1 & Macroinvertebrates \\
\hline 34 & Season of year & 1 & Fish \\
\hline 35 & Tree removal & 1 & $\begin{array}{l}\text { Fungi, } \\
\text { macroinvertebrates, } \\
\text { plants }\end{array}$ \\
\hline 36 & Type of local climate & 1 & Fish \\
\hline 37 & $\begin{array}{l}\text { Type of mining } \\
\text { operation }\end{array}$ & 1 & Fish \\
\hline 38 & Water depth & 1 & Plants \\
\hline
\end{tabular}

3). Both the variables themselves and the states associated with the highest/best response value overlapped with variables identified as important and their states as required for other taxa. The habitat requirements for birds (variable states) completely overlapped with those identified for mammals $(n=6)$, and almost entirely for amphibians $(n=8$ in common out of 9 identified requirements for amphibians). While fish were the most common focus of BBNs in freshwater wetlands (i.e., floodplain wetlands, wet meadows, polders, and ponds), they were also the taxa with the greatest number of unique habitat requirements ( $n=4$ variables unidentified in studies of other taxa as important).

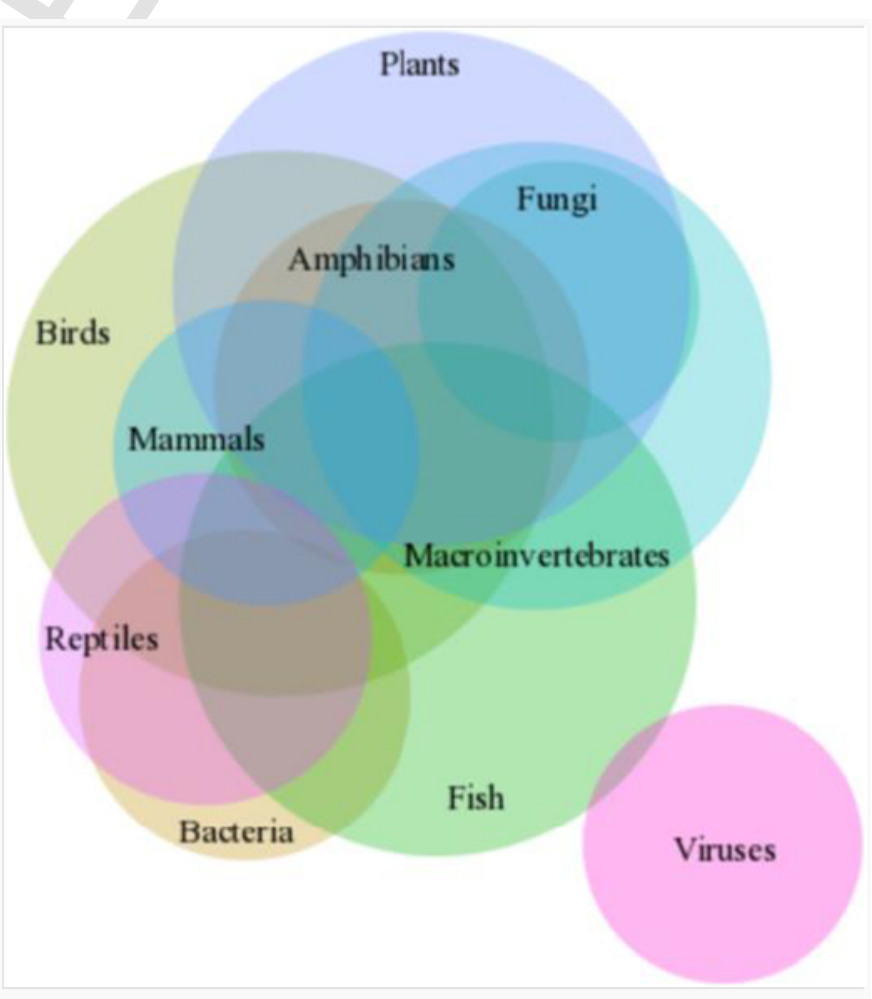

Fig. 3. Venn diagram showing the proportional overlap of habitat requirements among freshwater wetland taxonomic groups. Lists of important habitat requirements were compiled from our review of species-specific BBN model literature $(n=38$ habitat features from 50 studies; Table 1; Appendix 1).Venn diagram showing the proportional overlap of habitat requirements among freshwater wetland taxonomic groups. Lists of important habitat requirements were compiled from our review of species-specific BBN model literature $(\mathrm{n}=38$ habitat features from 50 studies; Table 1; Appendix 1). 


\section{Discussion}

\subsection{Using BBNs to identify candidate umbrella taxa}

The taxon-centered BBN models used to inform our umbrella taxa investigation for wetland conservation identified important habitat features (variables and states of variables) for freshwater wetland-dependent taxa. These shared habitat requirements across taxonomic groups can be used to leverage conservation choices that would benefit multiple species. For example, the models in our review indicated that maintaining appropriate hydrologic regimes and natural buffer areas surrounding wetlands would benefit multiple taxa. However, the top habitat features among taxon-centered BBNs were drawn from models built independently from one another to address specific local problems. The present lack of clarity in terminology and definitions makes it difficult to draw conclusions across taxa (e.g., Is the 'regular flooding or irrigation' node for one taxa equivalent to the 'predictable timing, extent, duration and frequency of flooding' node for another taxa?). Thus, to identify ecosystem-wide umbrella taxa, it would be beneficial to develop a standard node set with consistency of variable states that accurately represents the ecosystem in question.

In support of their use as umbrella taxa in freshwater wetland ecosystems, we found that birds had the greatest degree of overlap among habitat requirements shared with other species. Characteristics that indicate wetland birds make strong candidates for umbrella taxa representing wetland conservation include their status as habitat specialists with large ranges sizes, and that they are moderately sensitive to human disturbance (Caro, 2010; Green et al., 2002; Kalinkat et al., 2017; King et al., 2006; Roberge and Agelstam, 2004). For example, multiple bird species show sensitivity to human-caused disturbance that drives behavioral responses in vigilance, fleeing, habitat selection, mating displays and parental investment which can have population and community-wide impacts (Frid and Dill, 2002). As many wetland birds are migratory (e.g., Ma et al., 2009; Skagen, 1997), leveraging conservation efforts across entire annual ranges of wetland birds could maximize restoration of wetland biodiversity under an umbrella taxa approach.

The adoption of an umbrella taxa approach to conservation plans should, however, be made with caution as even under circumstances when umbrella taxa overlap spatially with rare or unique species, management decisions centered on umbrella taxa can cause unintended loss of non-target biodiversity (Severns and Moldenke, 2010). Although we did not consider issues of scale in our review, we recommend considering it when selecting umbrella species using BBNs or other methods to identify umbrella taxa. Unique landscape features important at regional scales continue to warrant the investigation of locally appropriate umbrella taxa (e.g., migratory fishes; Agostinho et al., 2005). Furthermore, the existence of species with unique habitat requirements or small ranges that do not overlap with umbrella taxa necessitate that conservation approaches maintain a breadth of strategies including programs surrounding focal taxa representative of unique habitats with specific threats (Lambeck, 1997).

\subsection{BBN model construction}

Bayesian belief network models are unique in their ability to incorporate expert opinion and refine the identification of sources of uncertainty by developing gamma models. If models rely heavily on expert opinion there is a danger that they do not adequately reflect reality due to linguistic uncertainty (when words have imprecise or different meanings to different people), overemphasis of rare cases stemming from specific memorable experiences by experts, or simply the reliance on memories and not empirical data (Meyer and Booker, 1991; Morgan and Henrion, 1990). A strength of BBNs is that they are also able to incorporate missing values in input data and perform accurate predictions with the model built from them (although not a unique to BBNs; Uusitalo, 2007). The development of gamma models (incorporating data to validate alpha or beta models) provides the opportunity to support or refute our understanding of relationships between species and their environment. Gamma models also enable refinement of identifying sources of uncertainty in resultant SDMs. To this end, we found that over half of the articles we reviewed validated their models with data. Through an iterative process of developing and updating BBN models with monitoring data, BBNs can provide an ideal modeling approach to facilitate adaptive management (Henriksen and Barlebo, 2008; Nyberg et al., 2006). Thus, a BBN approach to understanding species distributions can be powerful due to improved accuracy in modeling species habitat relationships.

As all models we reviewed were process models (with the exception of one dynamic model), seasonal processes are currently inadequately represented for the comparison of BBN models either within or among wetland types. Wetlands are, by definition, a hydrologically dynamic ecosystem defined by seasonal hydroperiod (Cowardin et al., 1979). The use of dynamic models that track habitat requirements across seasons may thus be more appropriate than the commonly used process models. However, there is an innate problem in finding convergence using Markov chains employed in dynamic BBN models which requires limiting the number of times the model can be updated (Wu et al., 2018). Further research developing BBNs as seasonal dynamic models could improve their utility in biological conservation.

Our review identified an overall lack of spatial statistical frameworks. In the absence of using spatial statistics, it may be difficult to identify when and where habitat is most likely needed to fulfill the life history needs of species within an ecosystem. Most wetland management initiatives focus on individual wetland creation, although strategic restoration planning may yield the greatest benefit using state-wide or watershed-wide perspectives (Horvath et al., 2017). Many challenges to wetland conservation planning could benefit from a spatially explicit, BBN approach. For example, wetland management remains challenging due to limited resources for acquiring new data (Margules et al., 2002), large areas of managed wetlands (Semlitsch and Bodie, 1998), limited ecological data on wetland characteristics and seasonal conditions (Zedler, 2000), and responses to changes in flow regimes in channelized river systems (Bunn and Arthington, 2002). Each of these issues could benefit from a spatially explicit risk assessment, to ease economic strain and use limited funds in the locations with the best cost-benefit ratio. However, many small-scale species requirements remain unavailable in spatial format (e.g., topographic, geomorphic, edaphic) and so are omitted from typical SDMs (Sinclair et al., 2010). Exclusions of these species can lead to error in SDMs, and few studies quantify the uncertainty generated by these incomplete data (Beale and Lennon, 2012; Elith and Leathwick, 2009).

Approaches to identifying umbrella taxa that employ a spatial statistical framework (e.g., clustering analyses such as calculating Ripley's K statistic, or other statistics for point processes) could improve the development of finer-scale range maps that can be used to aid in identifying areas of conservation priority. The use of a spatial statistical framework in a BBN approach would include node-specific estimates of uncertainty in probabilities of species occurrence with respect to environmental data gathered from a variety of sources (e.g., expert opinion from systems experts and curated GIS layers). Some new computational tools for calculating risk assessments of alternative conservation actions; including spatial statistical approaches for identifying important areas for conservation; are currently in beta testing through the GeoNetica (GeoNetica $^{\mathrm{TM}}$, Norsys Software Corporation) plug-in of the popular BBN computational tool, Netica (Netica 6.0, Norsys Software Corporation). 
Building spatially scalable wetland models that can accommodate the seasonal ranges in hydrological nodes, as well as differences in mobility of wetland taxa (e.g., pollinator vs. amphibian vs. riverine fish vs. migratory bird) may also aid in efforts to identify umbrella taxa in seasonal ecosystems. The complexity of seasonally fluctuating ecosystems, such as wetlands, therefore requires either the logical integration of multiple process models, or small dynamic BBN models (e.g., four seasons) equipped with scalability options to inform conservation plans appropriate for each season and location.

Although alpha models in our review were appropriately developed using empirical literature and combined with information provided by taxonomic experts to create beta models, ecological BBNs may benefit from also interviewing ecosystem experts. Particularly in wetlands, experts knowledgeable of hydrology and geomorphology could provide information regarding systems processes that likely influence physical habitat characteristics. For example, the frequency and timing of flooding in wetlands was important in many of the BBN models that we reviewed but there was little reference to the source of floodwaters. It was unclear whether floodwater resulted from rainfall (as in playa wetlands, ombrotrophic bogs or pocosins), river connection (as in alluvial swamps, montane or streamside wetlands), groundwater discharge (as in discharge wetlands such as prairie potholes, or fens) or whether water pumped into wetlands from a municipal source was sufficient (wetland hydrological characteristics from Brinson, 1993). Similarly, pedologists or edaphologists would know the types of plants best suited to soil characteristics and identify potential wetland areas for restoration given regional soil characteristics. The current lack of distinction among similar nodes across taxon-centered BBN models of freshwater wetlands is a major caveat because we lack relevant take-away actions for wider conservation planning. Including systems experts in the design of ecological BBN models may improve the use of BBNs as decision-support tools for conservation planning as they would enable higher accuracy in distinguishing relevant landscape variables at the ecosystem scale.

\subsection{BBNs as tools for biological conservation of freshwater wetlands}

Our review produced mixed results with respect to the integration of BBNs into biological conservation. On the one hand, the majority of peer-reviewed articles were funded by government agencies with a primary mission to support applied research. On the other hand, the majority of literature sources appeared in journals contributing to conservations among modelers, not in journals likely to inform wetland management and conservation communities. In general, even when the primary purpose of developing taxon-centered BBN models is for use as a decision-support tool for conservation planning, few studies fully transition from pilot to implementation. The majority of management decisions are not developed using decision-support tools, even when the primary purpose of developing taxon-centered BBNs is for future use as a decision-support tool for conservation planning. Although there have been consistent calls in the conservation literature for mechanistic models in defining species-habitat associations (i.e., those that test a specific mechanism driving species ooutcomes; Landuyt et al., 2013; McCann et al., 2006; Nyberg et al., 2006), this failure is not unique to BBNs. In a survey of over 1000 protected areas in Australia, Cook et al. (2010) found that approximately $60 \%$ of management decisions relied primarily on experience-based information. Sutherland et al. (2004) found that only $2 \%$ of conservation actions undertaken in an English wetland were based on verifiable evidence, while $77 \%$ of actions were based entirely on experience. A major hurdle supported by statements in almost all articles in our review was that taxon-centered BBNs were not adopted as support tools by land managers responsible for conservation.

Conservation planning may understandably dismiss species-specific BBNs due to a misguided assumption (from a modeling perspective) that BBNs are built considering the inappropriate landscape settings and may fail to include relevant dynamic physical features of the ecosystem if they are built exclusively through a taxonomic lens. Disconnection between the scientific research community and area managers occurs when scientific information is acquired and assembled without consideration of management implications, the results are not easily accessible or applicable to area managers (Bouska et al., 2016; Cook et al., 2012; Pullin and Knight, 2005), or there are perceived conflicts between single taxa model recommendations and the needs of multiple species in a complex system. Some attribute the limited adoption of decision-support tools by conservation planners to a lack of engagement between researchers and managers across multiple studies (Gawne et al., 2012; Goosen et al., 2007; Kroon et al., 2009), although adaptive resource management through collaborative efforts has been adopted in some areas (King et al., 2010; Richter and Thomas, 2007). Wetland restoration is thought to be effective at restoring both biodiversity and ecosystem services (Meli et al., 2014). Thus, the development of decision-support tools, such as BBNs, that synergize empirical data with expert knowledge from within a hypothesis-testing framework have the potential to drive critical gains in selecting effective criteria for conservation action if they were framed for more widespread utility.

\subsection{Conclusion}

The adoption of a systems-oriented BBN approach to conservation planning could aid the identification of effective umbrella taxa. The identification of umbrella taxa is often hindered by inconsistent methods for determining habitat requirements in species distribution models as well as inadequate prior knowledge of biotic and abiotic landscapes. As BBNs can include expert knowledge, they may provide a more robust assessment of ecosystems and improve conservation planning. As a decision-support tool for conservation planning, BBNs can be updated via monitoring to minimize uncertainties over time to achieve more rapid restoration success.

Although an umbrella approach to conservation may not protect habitat requirements for all species, comparing habitat requirements using a BBN approach to building species distribution models, as discussed here, allows for the identification of umbrella species. A BBN approach to identifying umbrella taxa can also quantitatively estimate which taxa may not benefit from conservation action targeted at umbrella taxa by identifying those with unique habitat requirements not shared with umbrellas. Thus, using a BBN approach to building SDMs has the potential to improve our capacity for effective biological conservation.

As BBNs are relatively easy to construct and understand due to their visual nature (Douglas and Newton, 2014), they have the potential to substantially improve coordinated efforts translating empirical research on species distributions into useable outputs in the hands of conservation planners. BBNs are flexible in their applicability and are particularly useful to build SDMs of data-poor species through the incorporation of expert knowledge (e.g., Drew and Collazo, 2014). Comparing important nodes and measures of uncertainty from multiple network models is a new methodology to identify critical habitat criteria shared across taxa. Using BBNs to identify taxa that have the highest degree of overlap in habitat requirements within an ecological community also enables a quantitative assessment of potential umbrella taxa which can then be the focus of conservation in an adaptive resource management framework. 
Supplementary data to this article can be found online at https:// doi.org/10.1016/j.biocon.2018.08.001.

\section{Acknowledgements}

We would like to thank the University of Missouri's School of Natural Resources Writing Workshop for their assistance in providing important feedback on early versions of this manuscript. We would also like to thank Dr. Ashton Drew and three anonymous reviewers for their assistance in reviewing and improving the manuscript. Primary funding for this project was provided by the Missouri Department of Conservation (MDC) via a Cooperative Agreement (\#402). The Missouri Cooperative Fish and Wildlife Research Unit is jointly sponsored by the MDC, the University of Missouri, the U.S. Fish and Wildlife Service, the U.S. Geological Survey, and the Wildlife Management Institute. Use of trade, firm, or product names is for descriptive purposes only and does not imply endorsement by the U.S. Government.

\section{References}

Adams, M.J., 1999. Correlated factors in amphibian decline: exotic species and habitat change in western. J. Wildl. Manag. 63, 1162-1171.

Agostinho, A., Thomaz, S., Gomes, L., 2005. Conservation of the biodiversity of Brazil's Inland Waters. Conserv. Biol. 19, 646-652. https://doi.org/10.1111/j.1523-1739.2005. 00701.x.

Andelman, S.J., Fagan, W.F., 2000. Umbrellas and flagships: efficient conservation surrogates or expensive mistakes?. Proc. Natl. Acad. Sci. U. S. A. 97, 5954-5959. https:// doi.org/10.1073/pnas.100126797.

Beale, C.M., Lennon, J.J., 2012. Incorporating uncertainty in predictive species distribution modelling. Philos. Trans. R. Soc. Lond. Ser. B Biol. Sci. 367, 247-258. https://doi. org/10.1098/rstb.2011.0178.

Bouska, K.L., Lindner, G.A., Paukert, C.P., Jacobson, R.B., 2016. Stakeholder-led science: Engaging resource managers to identify science needs for long-term management of floodplain conservation lands. Ecol. Soc. 21, https://doi.org/10.5751/ ES-08620-210312.

Brinson, M.M., 1993. A hydrogeomorphic classification for wetlands. In: Wetlands Research Program Technical Report WRP-DE-4, Vicksburg, MS.

Brudvig, L., 2011. The restoration of biodiversity: where has research been and where does it need to go?; the restoration of biodiversity: where has research been and where does it need to go?. Am. J. Bot. 98, 549-558. https://doi.org/10.3732/ajb.1000285.

Bunn, S.E., Arthington, A.H., 2002. Basic principles and ecological consequences of altered flow regimes for aquatic biodiversity. Environ. Manag. 30, 492-507. https://doi.org/ 10.1007/s00267-002-2737-0.

Caro, T., 2010. Conservation by Proxy: Indicator, Umbrella, Keystone, Flagship, and Other Surrogate Species. Island Press, Washington, D.C.

Caro, T.M., O'Doherty, G., 1999. On the use of surrogate species in conservation biology. Conserv. Biol. 13, 805-814. https://doi.org/10.1046/j.1523-1739.1999.98338.x.

Cayuela, L., Golicher, D.J., Newton, A.C., Kolb, M., de Alburquerque, F.S., Arets, E.J.M.M., Alkemade, J.R.M., Pérez, A.M., 2009. Species distribution modeling in the tropics: problems, potentialities, and the role of biological data for effective species conservation. Trop. Conserv. Sci. 2, 319-352. https://doi.org/10.1177/194008290900200304.

Chee, Y.E., Wilkinson, L., Nicholson, A.E., Quintana-Ascencio, P.F., Fauth, J.E., Hall, D., Ponzio, K.J., Rumpff, L., 2016. Modelling spatial and temporal changes with GIS and spatial and dynamic Bayesian networks. Environ. Model. Softw. 82, 108-120. https:// doi.org/10.1016/j.envsoft.2016.04.012.

Cook, C.N., Hockings, M., Carter, R., 2010. Conservation in the dark? The information used to support management decisions. Front. Ecol. Environ. 8, 181-186. https://doi. org $/ 10.1890 / 090020$.

Cook, C.N., Carter, B., Fuller, R.A., Hockings, M., 2012. Managers consider multiple lines of evidence important for biodiversity management decisions. J. Environ. Manag. 113, 341-346. https://doi.org/10.1016/j.jenvman.2012.09.002.

Cowardin, L.M., Carter, V., Golet, F.C., Laroe, E.T., 1979. Classification of Wetlands and Deepwater Habitats of the United States. FWS/OBS-79/31, Washington, DC.

Dibner, R.R., Doak, D.F., Murphy, M., 2017. Discrepancies in occupancy and abundance approaches to identifying and protecting habitat for an at-risk species. Ecol. Evol. 7, 5692-5702. https://doi.org/10.1002/ece3.3131.

Douglas, S.J., Newton, A.C., 2014. Evaluation of Bayesian networks for modelling habitat suitability and management of a protected area. J. Nat. Conserv. 22, 235-246. https: //doi.org/10.1016/j.jnc.2014.01.004

Drew, C.A., Collazo, J.A., 2014. Bayesian Networks as a Framework to Step-down and Support Strategic Habitat Conservation of Data-poor Species: A Case Study with King Rail (Rallus elegans) in Eastern North Carolina and Southeastern Virginia.

Dudgeon, D., Arthington, A.H., Gessner, M.O., Kawabata, Z.-I., Knowler, D.J., Lévêque, C., Naiman, R.J., Prieur-Richard, A.-H., Soto, D., Stiassny, M.L.J., Sullivan, C.A., 2006. Freshwater biodiversity: importance, threats, status and conservation challenges. Biol. Rev. 81, 163. https://doi.org/10.1017/S1464793105006950.
Elith, J., Leathwick, J.R., 2009. Species distribution models: ecological explanation and prediction across space and time. Annu. Rev. Ecol. Evol. Syst. 40, 677-697. https:// doi.org/10.1146/annurev.ecolsys.110308.120159.

Elith, J., Graham, C.H., Anderson, R.P., Dudik, M., Ferrier, S., Guisan, A., Hijmans, R.J., Huettmann, F., Leathwick, J.R., Lehmann, A., Li, J., Lohmann, L.G., Loiselle, B.A., Manion, G., Moritz, C., Nakamura, M., Nakazawa, Y., Overton, J.M., Peterson, A.T., Phillips, S.J., Richardson, K., Scachetti-Pereira, R., Schapire, R.E., Soberon, J., Williams, S., Wisz, M.S., Zimmermann, N.E., 2006. Novel methods improve prediction of species' distributions from occurrence data. Ecography 29, 129-151. https://doi. org/10.1111/j.2006.0906-7590.04596.x.

Findlay, C.S., Houlahan, J., 1997. Anthropogenic correlates of species richness in Southeastern Ontario Wetlands. Conserv. Biol. 11, 1000-1009. https://doi.org/10.1046/j. 1523-1739.1997.96144.x.

Fleishman, E., Murphy, D.D., Brussard, P.F., 2000. A new method for selection of umbrella species for conservation planning. Ecol. Appl. 10, 569-579. https://doi.org/10.1890/ 1051-0761(2000)010[0569:ANMFSO]2.0.CO;2.

Frid, A., Dill, L., 2002. Human-caused disturbance stimuli as a form of predation risk. Conserv. Ecol. 6.

Galat, D.L., Fredrickson, L.H., Humburg, D.D., Bataille, K.J., Bodie, J.R., Dohrenwend, J., Gelwicks, G.T., Havel, J.E., Helmers, D.L., Hooker, J.B., Jones, J.R., Knowlton, M.F., Kubisiak, J., Mazourek, J., McColpin, A.C., Renken, R.B., Semlitsch, R.D., 1998. Flooding to restore connectivity of regulated, large-river wetlands: natural and controlled flooding as complementary processes along the lower Missouri River. Bioscience 48 , 721-733. https://doi.org/10.2307/1313335.

Gawne, B., Price, A., Koehn, J.D., King, A.J., Nielsen, D.L., Meredith, S., Beesley, L., Vilizzi, L., 2012. A Bayesian belief network decision support tool for watering wetlands to maximise native fish outcomes. Wetlands 32, 277-287. https://doi.org/10.1007/ s13157-011-0255-7.

Goosen, H., Janssen, R., Vermaat, J.E., 2007. Decision support for participatory wetland decision-making. Ecol. Eng. 30, 187-199. https://doi.org/10.1016/J.ECOLENG.2006. 11.004 .

Green, A.J., El Hamzaoui, M., El Agbani, M.A., Franchimont, J., 2002. The conservation status of Moroccan wetlands with particular reference to waterbirds and to changes since 1978. Biol. Conserv. 104, 71-82. https://doi.org/10.1016/ S0006-3207(01)00155-0.

Guisan, A., Thuiller, W., 2005. Predicting species distribution: offering more than simple habitat models. Ecol. Lett. 8, 993-1009. https://doi.org/10.1111/j.1461-0248.2005. 00792.x.

Guisan, A., Zimmermann, N.E., 2000. Predictive habitat distribution models in ecology Ecol. Model. 135, 147-186.

Henriksen, H.J., Barlebo, H.C., 2008. Reflections on the use of Bayesian belief networks for adaptive management. J. Environ. Manag. 88, 1025-1036. https://doi.org/10.1016/ J.JENVMAN.2007.05.009.

Horvath, E.K., Christensen, J.R., Mehaffey, M.H., Neale, A.C., 2017. Building a potential wetland restoration indicator for the contiguous United States. Ecol. Indic. 83, 463-473. https://doi.org/10.1016/j.ecolind.2017.07.026.

Jones, J., 2001. Habitat Selection Studies in Avian Ecology: A Critical Review. Comment. Auk 118, 557-562.

Kalinkat, G., Cabral, J.S., Darwall, W., Ficetola, G.F., Fisher, J.L., Giling, D.P., Gosselin, M.P., Grossart, H.P., Jähnig, S.C., Jeschke, J.M., Knopf, K., Larsen, S., Onandia, G., Pätzig, M., Saul, W.C., Singer, G., Sperfeld, E., Jarić, I., 2017. Flagship umbrella species needed for the conservation of overlooked aquatic biodiversity. Conserv. Biol. 31, 481-485. https://doi.org/10.1111/cobi.12813.

Kearney, M., Porter, W., 2009. Mechanistic niche modelling: combining physiological and spatial data to predict species' ranges. Ecol. Lett. 12, 334-350. https://doi.org/10. 1111/j.1461-0248.2008.01277.x.

Kerbes, R.H., Kotanen, P.M., Jefferies, R.L., And, T., 1990. Destruction of wetland habitats by lesser snow geese: a keystone species on the west coast of Hudson Bay. J. Appl. Ecol. 27, 242-258.

King, S., Twedt, D., Wilson, R.R., 2006. The role of the wetland reserve program in conservation efforts in the Mississippi River Alluvial Valley. Wildl. Soc. Bull. 34, 914-920. https://doi.org/10.2193/0091-7648(2006)34[914:TROTWR]2.0.CO;2.

King, S., Elphick, C.S., Guadagnin, D., Taft, O., Amano, T., 2010. Effects of landscape features on waterbird use of rice fields. Waterbirds 33, 151-159. https://doi.org/10. 1675/063.033.s111.

Knutson, M.G., Sauer, J.R., Olsen, D.A., Mossman, M.J., Hemesath, L.M., Lannoo, M.J., 1999. Effects of landscape composition and wetland fragmentation on frog and toad abundance and species richness in Iowa and Wisconsin, U.S.A. Conserv. Biol. 13, 1437-1446. https://doi.org/10.1046/j.1523-1739.1999.98445.x.

Kroon, F.J., Robinson, C.J., Dale, A.P., 2009. Integrating knowledge to inform water quality planning in the Tully-Murray basin, Australia. Mar. Freshw. Res. 60, 1183. https: //doi.org/10.1071/MF08349.

Lambeck, R.J., 1997. Focal species: a multi-species umbrella for nature conservation. Conserv. Biol. 11, 849-856. https://doi.org/10.1046/j.1523-1739.1997.96319.x.

Landuyt, D., Broekx, S., D'Hondt, R., Engelen, G., Aertsens, J., Goethals, P.L.M., 2013. A review of Bayesian belief networks in ecosystem service modelling. Environ. Model. Softw. 46, 1-11. https://doi.org/10.1016/j.envsoft.2013.03.011.

Launer, A.E., Murphy, D.D., 1994. Umbrella species and the conservation of habitat fragments: a case of a threatened butterfly and a vanishing grassland ecosystem. Biol. Conserv. 69, 145-153. https://doi.org/10.1016/0006-3207(94)90054-X.

Lehtinen, R.M., Galatowitsch, S.M., 2001. Colonization of restored wetlands by amphibians in Minnesota. Am. Midl. Nat. 145, 388-396.

Lin, Y.-P., Lin, W.-C., Anthony, J., Ding, T.-S., Mihoub, J.-B., Henle, K., Schmeller, D.S., 2018. Assessing uncertainty and performance of ensemble conservation planning 
strategies. Landsc. Urban Plan. 169, 57-69. https://doi.org/10.1016/J.LANDURBPLAN. 2017.08.007.

Littell, J.S., Terando, A.J., Morelli, T.L., 2017. Balancing research and service to decision makers. Front. Ecol. Environ. 15, 598. https://doi.org/10.1002/fee.1739.

Ma, Z., Wang, Y., Gan, X., Li, B., Cai, Y., Chen, J., 2009. Waterbird population changes in the wetlands at chongming dongtan in the yangtze river estuary, China. Environ. Manag. 43, 1187-1200. https://doi.org/10.1007/s00267-008-9247-7.

Marcot, B.G., Steventon, J.D., Sutherland, G.D., McCann, R.K., 2006. Guidelines for developing and updating Bayesian belief networks applied to ecological modeling and conservation. Can. J. For. Res. 36, 3063-3074. https://doi.org/10.1139/x06-135.

Margules, C.R., Pressey, R.L., Williams, P.H., 2002. Representing biodiversity: data and procedures for identifying priority areas for conservation. J. Biosci. 27, 309-326.

Maslo, B., Leu, K., Faillace, C., Weston, M.A., Pover, T., Schlacher, T.A., 2016. Selecting umbrella species for conservation: a test of habitat models and niche overlap for beach-nesting birds. Biol. Conserv. 203, 233-242. https://doi.org/10.1016/j.biocon. 2016.09.012.

McCann, R.K., Marcot, B.G., Ellis, R., 2006. Bayesian belief networks: applications in ecology and natural resource management. Can. J. For. Res. 36, 3053-3062. https://doi. org/10.1139/x06-238.

Meli, P., María, J., Benayas, R., Balvanera, P., Ramos, M.M., Hajibabaei, M., 2014. Restoration enhances wetland biodiversity and ecosystem service supply, but results are context- dependent: a meta-analysis. PLoS One 9, https://doi.org/10.1371/journal.pone. 0093507.

Meyer, M.A., Booker, J.M., 1991. Eliciting and Analyzing Expert Judgement: A Practical Guide. Academic Press, London.

Morgan, M.G., Henrion, M., 1990. Uncertainty: A Guide to Dealing with Uncertainty in Quantitative Risk and Policy Analysis. Cambridge University Press, Cambridge.

Nyberg, J.B., Marcot, B.G., Sulyma, R., 2006. Using Bayesian belief networks in adaptive management 1. Can. J. For. Res. 36, 3104-3116. https://doi.org/10.1139/X06-108.

O'Hagan, A., 2012. Probabilistic uncertainty specification: overview, elaboration techniques and their application to a mechanistic model of carbon flux. Environ. Model. Softw. 36, 35-48.

Ozaki, K., Isono, M., Kawahara, T., Iida, S., Kudo, T., Fukuyama, K., 2006. A mechanistic approach to evaluation of umbrella species as conservation surrogates. Conserv. Biol. 20, 1507-1515. https://doi.org/10.1111/j.1523-1739.2006.00444.x.

Phillips, N.D., Reid, N., Thys, T., Harrod, C., Payne, N.L., Morgan, C.A., White, H.J., Porter, S., Houghton, J.D.R., 2017. Applying species distribution modelling to a data poor, pelagic fish complex: the ocean sunfishes. J. Biogeogr. 44, 2176-2187. https://doi. org/10.1111/jbi.13033.

Pullin, A.S., Knight, T.M., 2005. Assessing conservation management's evidence base: a survey of management-plan compilers in the United Kingdom and Australia. Conserv. Biol. 19, 1989-1996. https://doi.org/10.1111/j.1523-1739.2005.00287.x.

Quesnelle, P.E., Fahrig, L., Lindsay, K.E., 2013. Effects of habitat loss, habitat configuration and matrix composition on declining wetland species. Biol. Conserv. 160, 200-208. https://doi.org/10.1016/j.biocon.2013.01.020.

Ramsar Convention Secretariat (Ed.), 2013. The Ramsar Convention Manual: A Guide to the Convention on Wetlands (Ramsar, Iran, 1971), 6th ed., Ramsar Convention Secretariat, Gland, Switzerland.

Richter, B.D., Thomas, G.A., 2007. Restoring environmental flows by modifying dam operations. Ecol. Soc. 12, https://doi.org/10.2307/26267852.

Roberge, J.-M., Agelstam, P., 2004. Usefulness of the umbrella species concept as a conservation tool. Conserv. Biol. 18, 76-85. https://doi.org/10.1111/j.1523-1739.2004. 00450.x.
Roth, T., Weber, D., 2007. Top predators as indicators for species richness? Prey species are just as useful. J. Appl. Ecol. 45, 987-991. https://doi.org/10.1111/j.1365-2664. 2007.01435.x.

Sattler, T., Pezzatti, G.B., Nobis, M.P., Obrist, M.K., Roth, T., Moretti, M., 2014. Selection of multiple umbrella species for functional and taxonomic diversity to represent urban biodiversity. Conserv. Biol. 28, 414-426 https://doi.org/10.1111/cobi.12213.

Seddon, P.J., Leech, T., 2008. Conservation short cut, or long and winding road? A critique of umbrella species criteria. Oryx 42, https://doi.org/10.1017/S003060530806119X.

Semlitsch, R.D., Bodie, J.R., 1998. Are small, isolated wetlands expendable?. Conserv. Biol. 12, 1129-1133. https://doi.org/10.1046/j.1523-1739.1998.98166.x.

Severns, P.M., Moldenke, A.R., 2010. Management tradeoffs between focal species and biodiversity: endemic plant conservation and solitary bee extinction. Biodivers. Conserv. 19, 3605-3609. https://doi.org/10.1007/s10531-010-9897-7.

Sinclair, S.J., White, M.D., Newell, G.R., 2010. How useful are species distribution models for managing biodiversity under future climates?. Ecol. Soc. 15, https://doi.org/10. $2307 / 26268111$

Skagen, S.K., 1997. Stopover Ecology of Transitory Populations: The Case of Migrant Shorebirds. Springer, New York, NY, 244-269. https://doi.org/10.1007/ 978-1-4757-2703-6 10.

Sowa, S., Annis, G., Morey, M., Diamond, D., 2007. A gap analysis and comprehensive conservation strategy for riverine ecosystems of Missouri. Ecol. Monogr. 77, 301-334. https://doi.org/10.1890/06-1253.1.

Stewart, D.R., Underwood, Z.E., Rahel, F.J., Walters, A.W., 2017. The effectiveness of surrogate taxa to conserve freshwater biodiversity. Conserv. Biol. https://doi.org/10. 1111/cobi.12967.

Suter, W., Graf, R.F., Hess, R., 2002. Capercaillie (Tetrao urogallus) and avian biodiversity: testing the umbrella-species concept. Conserv. Biol. 16, 778-788. https://doi.org/10. 1046/j.1523-1739.2002.01129.x.

Sutherland, W.J., Pullin, A.S., Dolman, P.M., Knight, T.M., 2004. The need for evidence-based conservation. Trends Ecol. Evol. 19, 305-308. https://doi.org/10.1016/ J.TREE. 2004.03.018.

Uusitalo, L., 2007. Advantages and challenges of Bayesian networks in environmental modelling. Ecol. Model. 203, 312-318 https://doi.org/10.1016/J.ECOLMODEL.2006. 11.033.

Wettstein, W., Schmid, B., 1999. Conservation of arthropod diversity in montane wetlands: effect of altitude, habitat quality and habitat fragmentation on butterflies and grasshoppers. J. Appl. Ecol. 36, 363-373. https://doi.org/10.1046/j.1365-2664.1999. 00404.x.

Wilcox, B.A., 1984. In situ conservation of genetic resources: Determinants of minimum area requirements. In: McNeely, J.A., Miller, K.R. (Eds.), Proceedings of the Selection of Umbrella Species World Congress on National Parks "National Parks, Conservation and Development.”. Smithsonian Institution Press, Washington, D.C., pp. 18-30.

Wood, K.A., Stillman, R.A., Hilton, G.M., 2018. Conservation in a changing world needs predictive models. Anim. Conserv. 21, 87-88. https://doi.org/10.1111/acv.12371.

Wu, P.P.-Y., Julian Caley, M., Kendrick, G.A., McMahon, K., Mengersen, K., 2018. Dynamic Bayesian network inferencing for non-homogeneous complex systems. J. R. Stat. Soc.: Ser. C: Appl. Stat. 67, 417-434. https://doi.org/10.1111/rssc.12228.

Zajac, Z., Stith, B., Bowling, A.C., Langtimm, C.A., Swain, E.D., 2015. Evaluation of habitat suitability index models by global sensitivity and uncertainty analyses: a case study for submerged aquatic vegetation. Ecol. Evol. 5, 2503-2517. https://doi.org/10.1002/ ece3.1520.

Zedler, J., 2000. Progress in wetland restoration ecology. Trends Ecol. Evol. 15, 402-407. 
We identified a total of 53 articles with ecological BBNs for freshwater wetland-dependent taxa; consisting of 33 peer-reviewed articles, 9 reports or conference proceedings, 10 master of science theses or doctoral dissertations, and 1 book chapter (Appendix 1). The sources of peer-review articles were primarily ecological journals (e.g., Ecological Indicators), the modeling journal, Environmental Modeling \& Software $(n=6)$, and conservation journals such as Biological Conservation $(n=2)$ and Conservation Biology $(n=1)$. Lead authorship on peer-reviewed articles and reports was rarely by graduate students or early-career scientists such as postdoctoral researchers (26\%), and more commonly by research fellows or senior researchers at the time of publication (Appendix 2).

The earliest evidence we found of BBNs being used to model habitat requirements of freshwater wetland species was from 2003, with an accelerated rate of increase in peer-reviewed literature using BBNs to explore habitat relationships of wetland taxa as years have gone on (Fig.
2). The majority of articles focused on Australasian wetlands (including Australia, Tasmania, Papua New Guinea, and New Zealand; 42\%), but wetlands from all continental regions (excepting Antarctica) have been represented by BBNs in the peer-reviewed literature (Appendix 1).

Based on information in the acknowledgements sections, the majority of peer-reviewed articles were funded through government agencies with a primary mission to support applied research to improve natural resource management, such the National Climate Change Adaptation Research Facility (Australia), the United States Fish and Wildlife Service (USA), and the United States Geological Survey (USA) (Appendix 2). There were fewer instances of funding from government agencies with a primary mission to advance science theory, such as the National Science Foundation (USA), the National Science Council (China) or the Natural Sciences and Engineering Research Council (Canada). Very few articles cited funding from nongovernmental organizations concerned with ecological restoration or biological conservation. Supplementary Figures 